\title{
Introduction: Penetrating Medieval Wounds
}

\author{
Larissa Tracy and Kelly DeVries
}

The human body is a container held together by a carefully constructed network of blood vessels, nerves, and ligaments, intertwined with a skeletal framework designed to shape and protect the delicate organs within, all wrapped neatly in a casing of skin. Any breaking of the skin through blunt or sharp-force trauma, any puncture or slash, laceration or abrasion, threatens the interior systems of the body. Wounds pierce and penetrate, permeate, and infect. Wounds allow access to the internal elements of the human body, revealing its vulnerabilities but also its strength and, in some cases, miraculous capacity to heal from even the most violent of injuries. Flesh can be wounded and knit back together by unguents, ointments, honey, sutures, plasters, bandages, and suppurations. A wound can indict, convict, acquit; wounds are legal entities, inflicted in the course of justice and injustice. They are adjudicated, measured, treated, compensated, and bound. They can also inspire, especially when a deity is defined in part by wounds carried after "death" to prove eternal life; when followers acquire those same wounds, they are deemed especially devout and holy. In the medieval world, wounds could be fatal or salvific; they represented the sacrifice of love - divine and earthly. They could be mutilating, proof of shame or valor. They could be the cause of lifelong admiration or endless poverty. They could bring temporary pain, quickly relieved by rest or alcohol, or lingering agony that ended only with death. They could be caused by all sorts of weapons - swung, thrust, or shot. They could be prevented by armor and treated by surgeons. They could end life or immortalize it.

Wounds were not simply injuries to the body; rather, they were often signifiers of class or status, and many were dealt with and compensated based on social standing. Holy wounds (divine manifestations, self-inflicted, or barbaric punishment) opened the sanctified body up to interpretation as well as infiltration by the Holy Spirit. Wounds occurred in a variety of ways and in a variety of venues. Not all were inflicted with malice. Some were the product of chivalric jousting, dueling, or trials by combat. Writing about the spectacle of wounding in medieval images, Mitchell Merback explains: "Once a wound appears before our eyes, it is as if a fault line has opened up across the body's topography, one that threatens to tear open ever wider expanses of the body's hidden interior." ${ }^{1}$ Witnessing the wounded body in art and in punitive

1 Mitchell B. Merback, The Thief, the Cross and the Wheel: Pain and the Spectacle of Punishment in Medieval and Renaissance Europe (London: Reaktion Books, 1999), 113. 
spectacle "delivers an inchoate shock, and causes such sympathetic perceptions of pain, because the wounded body of our vision somehow ceases to be that body and becomes, in an uncanny way, our body as well."

Outside of artistic or judicial spectacles, medieval people were exposed to real, literal, wounds in multiple ways, often (but not always) responding to them and treating them with a certain level of calm and coherence. Healing wounds was just as significant a part of medieval practice as inflicting them or punishing the infliction. Surgical treatises offer clinical assessments of wounds and treatments, while battlefield accounts and fencing manuals describe how armor and technique were meant to prevent serious injury. Wounds feature heavily in chivalric literature and form the centerpiece of medieval conceptions of heroism and masculinity. Wounds were a function of fragmentation, the body separated into parts, penetrated and revealed. Wounds manifest anxieties about dislocation and dismemberment that figure into debates about the dichotomy of the body and the soul, and the resurrection of the body at the Last Judgment prevalent after the Fourth Lateran Council (1215). ${ }^{3}$ Wounding the body was often thought to wound the soul.

\section{The Medieval Body}

A wounded body, especially one that was tortured or dismembered, may sever the connection with the soul or tear it apart. There is a profound relationship between pain and suffering and the body-soul union. ${ }^{4}$ Wounding the body through penal practice, punishment, interrogatory torture, and even in the course of battle, endangers the integrity of the physical container and, thus, the soul. Caroline Walker Bynum attributes the increasing fascination with brutality and dismemberment to a shift in ethos despite cultural fears about fragmentation, permitting division of the body that was practiced on an increasing scale in the thirteenth century. The evolution of surgical procedure at the same time is part of this development; the first examples of autopsy to determine the cause of death in legal cases appear in the thirteenth century, and "the first official dissections were carried out in medical schools in the

2 Merback, The Thief, the Cross and the Wheel, 113.

3 See: Caroline Walker Bynum, Fragmentation and Redemption: Essays on Gender and the Human Body in Medieval Religion (New York: Zone Books, 1992), 270-1.

4 Donald Mowbray, Pain and Suffering in Medieval Theology: Academic Debates at the University of Paris in the Thirteenth Century (Woodbridge: The Boydell Press, 2009), 16. 
years around 1300, for purposes of teaching as well as diagnosis." ${ }^{5}$ The clinical approach to the body as an entity that can be dissected or disarticulated mirrors the callous application of torture in judicial proceedings which relies on seeing the body as an entity unconnected from the consciousness or as means of controlling the conscious response. Bynum draws a connection between the rise of surgical procedure, the revival of torture as a judicial practice, the significant increase in the use of mutilation and dismemberment to punish capital crimes, and the dissemination of saints' relics based on miraculous hagiographical accounts. In many of these cases, the spectacle of the wounded body is designed to affect a visceral audience response. Those who see an injury will respond to injuries and to wounds "as an imaginary wound in an imaginary body, despite the fact that that imaginary body is itself made up of thousands of real human bodies, and thus composed of actual (hence woundable) human tissue." 6 The suffering engendered by wounds is not always a facet of medieval narratives. Very often, the pain that accompanies the wound is neither evident nor expressed; in hagiography, withstanding the wound and experiencing only solace is part of the sanctifying aspect of injury. Either way, wounds are a way of articulating and vivifying - investing with life - the "idea of strategic vulnerability."7

That was because wounds could be so severe, life changing, both physically and mentally. Soldiers understood physical wounds, especially that they needed to be treated in some haste; wounds could be patched up, although not always successfully, as Richard the Lionheart discovered after being shot just below the neck in the left shoulder by a low-born, inexperienced crossbowman - a man whom the king eventually pardoned. Battle wounds should have been easily and successfully treated but, instead, many turned

5 Caroline Walker Bynum, Fragmentation and Redemption, 270-2. See also: Larissa Tracy, Torture and Brutality in Medieval Literature: Negotiations of National Identity (Cambridge: D.S. Brewer, 2012), 51 n. 76.

6 Elaine Scarry, The Body in Pain: The Making and Unmaking of the World (Oxford: Oxford University Press, 1985), 71.

7 Scarry, The Body in Pain, 71. Several excellent studies analyze the nature of wounding and the effects on the body in more theoretical terms. See: Caroline Walker Bynum, Wonderful Blood: Theology and Practice in Late Medieval Northern Germany and Beyond (Philadelphia: University of Pennsylvania Press, 2007); Peggy McCracken, The Curse of Eve, the Wound of the Hero: Blood, Gender, and Medieval Literature (Philadelphia: University of Pennsylvania Press, 2003); Bettina Bildhauer, Medieval Blood (Cardiff: University of Wales Press, 2006); Esther Cohen, The Modulated Scream: Pain in Late Medieval Culture (Chicago: University of Chicago Press, 2010), among others. 
gangrenous, agonizing, and, eventually, fatal. ${ }^{8}$ But the psychological wounds that often accompanied the physical ones - what we might call "Post Traumatic Stress Syndrome (PTSD)" today, "battle exhaustion" in World War II, "shell shock" in World War I, and "cowardice" for most of the world's history - were not understood. In medieval sources where they are infrequently identified, these manifest in a variety of ways from melancholy and religious reflection to machismo and ostentatious displays of masculinity. ${ }^{9}$

\section{Historiography}

The world has been excited by the discovery of the skeletal remains of King Richard III in August 2012 - with good cause. His death was immortalized in Shakespeare's line: "a horse, a horse, my kingdom for a horse,"10 but his body had been lost since the battle of Bosworth, fought on 22 August 1485, when he was slain in the decisive usurpation of Henry Tudor. There was a persistent belief that his remains had been deposited without fanfare at Greyfriars in Leicester, the city closest to the battlefield; ironically the battlefield was also lost until recently. ${ }^{11}$ The Reformation of Henry viII, son of the Bosworth victor, was not kind to medieval Catholic churches and monasteries, and Greyfriars (dissolved in 1538), was among those that fell into ruin. Hence, when Richard's body was eventually uncovered, along with the remains of the abbey itself, it lay rather ignobly under a parking lot.

This was a remarkable find, but what happened afterwards was unprecedented. Gathering a team of experts from all applicable fields, Richard's bones were extensively studied. All modern technologies were used to determine first that it was Richard's body - matched by DNA to two descendants of his sister - and then, among several other things, how he was killed. Contemporary sources only indicated that he had been dragged from his horse and killed.

8 Jean Flori, Richard the Lionheart: Knight and King, trans. Jean Birrell (Edinburgh: Edinburgh University Press, 1999), 233-54.

9 The most excessive of the latter perhaps displayed by the famous fifteenth-century Italian condottiere, Federico III da Montefeltro, who appears to have surgically removed the top part of his nose after a wound to his right eye impeded his sight during fighting. Henri P.J. Winters, "Federico da Montefeltro, Duke of Urbino (1422-82): The Story of His Missing Nasal Bridge," British Journal of Plastic Surgery 35 (1982): 247-50.

10 William Shakespeare, Richard the Third, ed. James R. Siemon (London: Arden, 2009), 5.4.7.

11 Glenn Foard and Anne Curry, Bosworth, 1485:A Battlefield Rediscovered (Oxford: Oxbow Books, 2013). 
How he was killed, by what weapons, and why his armor did not protect him remained a mystery until after the exhumation. Several wounds were revealed in the skeletal study, three of which might have been the coup de grace; those studying the body have also suggested what weapons caused his wounds, that his helmet may have been stripped off, leaving his head (where most of the perimortal wounds were) unprotected. Questions remain, like the order in which the wounds occurred, for example; however, the revelations relating to this anomalous artifact have advanced investigations, into not only Richard III and his death, but also into many other facets of medieval studies. ${ }^{12}$

Research into medieval wounds and wound repair has advanced very far and in a relatively short time. ${ }^{13}$ Since the early twentieth century, many sites have been excavated, some with bodies, but the causes of death, for even those who died violently, were rarely studied. ${ }^{14}$ This changed in 1905 with the chance

See: Robert C. Woosnam-Savage and Kelly DeVries, "Battle Trauma in Medieval Warfare: Wounds, Weapons and Armor," in this volume, 27-56; and Jo Appleby, Guy N. Rutty, Sarah V. Hainsworth, Robert C. Woosnam-Savage, Bruno Morgan, Alison Brough, Richard W. Earp, Claire Robinson, Turi E. King, Mathew Morris, and Richard Buckley, "Perimortem Trauma in King Richard III: A Skeletal Analysis," The Lancet 385.9964 (17-23 September 2014): 253-59. Richard III is a particularly unique case because the historical contexts regarding his death - first-hand (and not-so-first-hand) accounts of the battle - can aid in possible interpretations of it, in conjunction with the newly discovered remains. According to Woosnam-Savage, the team examining Richard's skeleton has been terribly aware of "speculation" and has only made suggestions regarding possible (though plausible) interpretations of his wounds (not flights of speculative fantasy) using historical accounts with the physical evidence, something that can be done very rarely. Anything is possible on the battlefield. However, Richard is arguably the exception that proves the rule because it would appear that some of the science can help inform history and some of the history can help inform science (Personal communication 30 Nov. 2014).

13 Medieval archaeology has been a field of research for many centuries, perhaps seriously begun in 1653 when the extremely rich tomb of the Frankish King Childeric I (died in 481 or 482) was uncovered in Tournai. Childeric's remains were not among the finds, however, and interest was paid mostly to the gold and jewels - almost all of which were unfortunately lost when they were stolen from Paris in 1831 and melted down. Twentieth-century excavations revealed a large number of horses buried with Childeric, but no human skeletons. A clear introduction to the tomb's items, shown in drawings made at the time, can be found in Patrick Geary, ed., Readings in Medieval History, vol. 1: The Early Middle Ages, 4th ed. (Toronto: University of Toronto Press, 2010), 113-21.

14 Examples of these skeletal exhumations are numerous and include individuals such as Charlemagne, Haakon v of Norway, St. Cuthbert, and at least three other English kings, John, Edward I and Edward Iv. For a further discussion of the importance of disinterment and reburial, see: Thea Tomaini, Death Fascination and Disinterment in England 1700-190o, forthcoming. 
find of burial pits on the Visby battlefield by soldiers from the Gotland Artillery Regiment who were building an arbor for their officers. Excavations conducted at the time, and in 1912, 1928-30, and 1939, eventually revealed the remains of 1185 bodies from the battle fought there in 1361, almost all of which exhibited evidence of wounds. Bo E. Ingelmark, in a position which would come to be called Forensic Archaeologist or Forensic Osteoarchaeologist, assembled extensive data from these wounds. He published his findings in 1939 with Bengt Thordeman's archaeological report on the artefacts found in the graves; they might have been forgotten had they not appeared in a simultaneous English translation under the oddly titled Armour from the Battle of Wisby, ${ }_{13} 61 .^{15}$ And just like that, a new field of medieval research was (if one might pardon the pun) unearthed.

But the study of wounds caused by medieval warfare had to be put on hold while a more modern war, World War II, engulfed the European continent. This conflict, combined with its counterpart theater in Asia and the Pacific, and later conflicts in Korea and Vietnam, as well as numerous colonial wars, greatly increased expertise in military medicine. ${ }^{16}$ Doctors and surgeons returning from those wars were interested in what they had achieved and what preceded it. They wrote scores of articles on the history of wound repair that appeared in medical journals as diverse as the Bulletin of the Los Angeles Neurological Societies and the British Journal of Plastic Surgery. ${ }^{17}$ While several of these studies have been superseded by later work applying more careful original historical research skills, they hold an important place in the historiography of military surgery when few others were being written.

The past three decades have seen advancement in both osteoarchaeological research and the history of wound repair. There have been more, and more careful, excavations and examinations of medieval human remains that suffered violent trauma, and earlier exhumed bodies have been re-examined. The

15 Bengt Thordeman, Poul Nörlund, Brian R. Price, and Bo. E. Ingelmark, Armour from the Battle of Wisby, 1361 (Stockholm: Almquist \& Wiksells Boktryckeri, 1939).

16 Richard A Getz and Karen S. Metz, A History of Military Medicine: From the Renaissance through Modern Times, vol. 2 (New York: Greenwood Press, 1992) is not a great survey of the period, but does note how much was learned from these modern conflicts.

See, among others: Cyril B. Courville and Harold Kade, "Split Fractures of the Skull Produced by Edged Weapons and their Accompanying Brain Wounds," Bulletin of the Los Angeles Neurological Societies 29 (1964): 32-39; Cyril B. Courville, "War Wounds of the Cranium in the Middle Ages," Bulletin of the Los Angeles Neurological Societies 30 (1965): 27-44; and Winters, "Federico da Montefeltro, Duke of Urbino (1422-82)." Included in this list should be the excellent historical studies by World War I veteran surgeon George Gask, which are gathered in Essays in the History of Medicine (London: Butterworth, 1950). 
study of more than 300 sets of remains from late Antiquity through the end of the fifteenth century, covering conflicts from the Fall of Rome through the Crusades to the Wars of the Roses, have built on the foundation laid by the Visby work of Bo E. Ingelmark. ${ }^{18}$ The studies by Piers D. Mitchell, whose background as an orthopedic surgeon provided a unique insight into examining excavated remains from various crusading and medieval English sites, have been especially influential. His culminating monograph, Medicine in the Crusades: Warfare, Wounds, and the Medieval Surgeon (2004), is a brilliant example of what the melding of scientific and historical research can achieve. ${ }^{19}$ Studies of bodies excavated from the battlefield of Towton in 1461 conducted by archaeologists, forensic scientists, and historians during the 1990s have also been important in setting a standard of research leading up to, and perhaps exceeded only by, the recent research undertaken on the remains of Richard III. $^{20}$

In their recent collection Medicine and the Law in the Middle Ages (2014), ${ }^{21}$ Wendy J. Turner and Sara M. Butler identify the need for an interdisciplinary approach to researching medieval medicine. Their invaluable study looks at the intersections of medical practice and law throughout medieval Europe in regards to mental health, monetary compensation for injury, childbirth, forensic evidence, surgical regulations, and medical licensing. Done largely from the perspective of historians investigating a wealth of diverse sources, Medicine and Law marks the beginning of a new wave of research into the significance of medicine in the medieval world. Anne Kirkham and Cordelia Warr's volume Wounds in the Middle Ages (2014) includes ten pieces that begin a conversation

18 For a catalogue of these excavations, see: Woosnam-Savage and DeVries, "Battle Trauma in Medieval Warfare," in this volume, 27-56.

19 Piers D. Mitchell, Medicine in the Crusades: Warfare, Wounds, and the Medieval Surgeon (Cambridge: Cambridge University Press, 2004). Mitchell's articles include: "Pathology in the Crusader Period: Human Skeletal Remains from Tel Jezreel," Levant 26 (1994): 67-71; "The Integration of the Palaeopathology and Medical History of the Crusades," International Journal of Osteoarchaeology 9 (1999): 333-43; "The Palaeopathology of Skulls Recovered from a Medieval Cave Cemetery near Safed, Israel (Thirteenth to Seventeenth Century)," Levant 36 (2004): 243-250; (with Y. Nagar, and R. Ellenblum), "Weapon Injuries in the Twelfth-Century Crusader Garrison of Vadum Iacob Castle, Galilee," International Journal of Osteoarchaeology 16 (2006): 145-55; and "The Torture of Military Captives to the Medieval Middle East," in Noble Ideals and Bloody Realities: Warfare in the Middle Ages, ed. Niall Christie and Maya Yazigi (Leiden: Brill, 2006), 97-118.

20 Veronica Fiorato, Anthea Boylston, and Christopher Knüsel, Blood Red Roses: The Archaeology of a Mass Grave from the Battle of Towton, AD 1461 (Oxford: Oxbow Books, 2000).

21 Wendy J. Turner and Sara M. Butler, eds., Medicine and the Law in the Middle Ages (Leiden: Brill, 2014). 
about the importance of wounds in medieval society. ${ }^{22}$ The product of a symposium held at the University of Manchester in 2011, Kirkham and Warr's collection considers aspects of wounding in medieval culture through the lens of modern medical practice largely in terms of military and religious conceptions of wounding and makes several valuable contributions to a growing body of scholarship. But there is much that remains to be done. ${ }^{23}$

\section{The Physicality of Wounds}

Recent advancements in technology, as well as the discovery of identifiable remains, have opened numerous possibilities for investigating the form and frequency of wounding, primarily on medieval battlefields. Arranged thematically by the kinds of wounds - physical, spiritual, and literary - and chronologically within each set of themes, our collection begins with the physical evidence of wounds and wound treatment, from catalogues of trauma on skeletal remains to case-studies on medical procedures for healing that trauma. Robert Woosnam-Savage and Kelly DeVries open this volume with a description of how medieval warfare frequently led to wounded soldiers who survived and how the written and archaeological evidence can determine what weapons made these wounds. They include a catalogue of several excavations of bodies that suffered violent sharp-force, blunt-force, or penetration trauma, which serves as a foundation for several of the following contributions. They provide evidence of a startling survival rate among wounded soldiers, even those who received wounds that one might expect to have been fatal, attributing this to the care of military surgeons and the protective capabilities of

22 Anne Kirkham and Cordelia Warr, eds., Wounds in the Middle Ages (Burlington, vT: Ashgate, 2014). Unfortunately Kirkham and Warr's volume appeared after the articles for our collection were written, and it was unavailable to most of our contributors.

Several studies have been done on the spectacle of medieval violence, many of which consider wounds in that context but they do not place the same focus on the wounds themselves or their healing. See, for example: Merback, The Thief, the Cross and the Wheel; Robert Mills, Suspended Animation: Pain, Pleasure, and Punishment in Medieval Culture (London: Reaktion Books Ltd., 2005); Mark D. Meyerson, Daniel Thiery, and Oren Falk, eds., 'A Great Effusion of Blood'?: Interpreting Medieval Violence (Toronto: University of Toronto Press, 2004); John Bellamy, Crime and Public Order in England in the Later Middle Ages (London: Routledge and Kegan Paul, 1973); Daniel Baraz, Medieval Cruelty: Changing Perceptions, Late Antiquity to the Early Modern Period (Ithaca: Cornell University Press, 2003); and Scarry, The Body in Pain. 
medieval armor. ${ }^{24}$ M.R. Geldof follows, explaining the significance of new techniques in studying and interpreting excavated remains; but he cautions that it is "necessary to evaluate how the archaeology of violence is interpreted, how it is studied for its social and cultural meaning, and where the limits to interpretation give way to speculation." ${ }^{25}$ Challenging modern misconceptions about what "truth" can actually be reconstructed from skeletal remains, ultimately, Geldof concludes that, while bone-evidence is important for forensic archaeologists, it is only one piece in the osteoarcheological puzzle and can only tell us so much about the consequences of medieval martial violence. In her contribution, Patricia Skinner engages with Geldof's proposition by considering the real life implications of wearing wounds in terms of social stigma (or honor) in a variety of contexts. She examines textual evidence regarding wounds from early medieval Europe, focusing her attention on variety of head wounds sustained in warfare and their social significance as well as the legal implications of wounds, scars, and the effect they had on individual status within a community. Skinner concludes that "that face wounds were a delicate subject (at least at the level of the elite) and/or that they were so commonplace that they, and the care received, merited little comment."26

Wounds were most often inflicted in warfare by those trained to use weapons for just such a purpose. But not every medieval battlefield wound was fatal. Like Skinner, Iain A. MacInnes investigates the existing corpus of records regarding injuries, but his focus is on Anglo-Scottish warfare from the late-thirteenth to the early-fifteenth centuries, and he is duly cautious of chronicle accounts that were exaggerated or simply implausible. Taken as a whole, the sources indicate that certain Scottish lords provided field doctors for their men wounded in battle, so that while injury was a high probability on the Scottish battlefield, so was surviving those injuries. ${ }^{27}$ Rachel E. Kellett goes further in dispelling the common misconception that medieval warfare was only about killing. Turning to the German fencing manuals, which were meant to prepare swordsmen for battle as well as for sport, rather than chronicle accounts of battle, Kellett looks closely at the anatomical placement of blows which suggest that while fencing was often a form of entertainment, the fencers were

\footnotetext{
24 Woosnam-Savage and DeVries, "Battle Trauma in Medieval Warfare," 47.

25 M.R. Geldof, "And to describe the shapes of the dead': Making Sense of the Archaeology of Armed Violence," in this volume, 57-80, at 59.

26 Patricia Skinner, "Visible Prowess? Reading Men's Head and Face Wounds in Early Medieval European Sources to $1000 \mathrm{CE}$," in this volume, 81-101, at 101.

27 Iain A. MacInnes, "Heads, Shoulders, Knees and Toes: Injury and Death in Anglo-Scottish Combat, c. 1296-c. 1403," in this volume, 102-27.
} 
also being trained to inflict wounds - even severe wounds. ${ }^{28}$ Fencing was practiced with dulled weapons (usually, but not always), but fencers learned vital skills for inflicting wounds on the battlefield with sharpened blades.

\section{Surgery}

From modes of inflicting and surviving wounds in war or sport, the volume moves into specific methods of treating wounds. As the previous selections suggest, inflicting wounds was only one facet of medieval life and warfare. As Woosnam-Savage and DeVries point out in their catalogue of physical remains, many people survived their wounds in the Middle Ages, and so several of the following contributions deal with the textual evidence of wounds and their repair, using one of the richest, and most obvious, sources - surgical texts. Many modern misconceptions about the Middle Ages suggest that medieval society was medically stunted, backwards, or primitive, and that treatments bordered on the ludicrous or downright dangerous. But numerous surgical texts circulated throughout medieval Europe and some offered more useful (and successful) treatments than others. Medieval surgery evolved from a complex system of text, practice, belief, transmission, science, and folklore. ${ }^{29}$ The first major medical center was twelfth-century Salerno, Sicily, where Christian and Muslim communities lived side by side. Many medieval medical and surgical texts and treatments reflect Muslim influence and, in some cases, origins.

There was an "efflorescence" of medicine and surgery in twelfth century Salerno, possibly because of Salerno's fortuitous position as a melting pot of Mediterranean cultures. ${ }^{30}$ The medical "school" of Salerno - an informal community of masters and pupils who developed more or less formal methods of instruction and investigation ${ }^{31}$ - became the center from which a large portion

28 Rachel E. Kellett, “....Vnnd schüß im vnder dem schwert den ort lang ein $\mathrm{zu}^{\mathrm{o}}$ der brust': The Placement and Consequences of Sword-blows in Sigmund Ringeck's Fifteenth-century Fencing Manual," in this volume, ${ }^{128-50}$, at 131.

Several excellent studies have been done on the development and practice of medieval surgery. See: Faye Getz, Medicine in the English Middle Ages (Princeton: Princeton University Press, 1998); Piers Mitchell, Medicine in the Crusades: Warfare, Wounds and the Medieval Surgeon (Cambridge: Cambridge University Press, 2004); and Tony Hunt, The Medieval Surgery (Woodbridge: Boydell Press, 1992).

30 Monica H. Green, ed. and trans., introduction to The Trotula: An English Translation of the Medieval Compendium of Women's Medicine (Philadelphia: University of Pennsylvania Press, 2002); 1-63, at 3-4.

31 Green, introduction, 9-10. 
of medieval medical knowledge and practice emanated. Europeans travelled hundreds of miles to seek the medical knowledge of the physicians in Salerno like Gariopontus. Frustrated by the disorganized, indecipherable texts available, he compiled the Passionarius that became a popular resource for practitioners throughout medieval Europe.$^{32}$ Gariopontus initiated a tradition of compiling and translating medical texts that would be carried on by successive generations of scholars: Alfanus translated Nemesius of Emesa's Greek On the Nature of Man into Latin (c. 1050); Constantine the African († before 1098/99) rendered more than twenty Arabic texts into Latin, including the Viaticum (the Latin title) of Abū Jar far Ahmad b. Ibrāhīm b. Abī Khālid al-Jazzār $(† 979) \cdot{ }^{33}$ Most medieval medicine had its roots in the work of Galen, which is itself grounded in Hippocrates' theories about bodily humors. The rise of universities in Italy, Spain, France, and England, ${ }^{34}$ and the continued production of works in Latin and vernaculars, led to the development of learned medicine. Works by Avicenna, Rhazes (al-Razi), Albucasis, and Galen, all translated by Gerard of Cermona, created a "richer terminology for learned medicine in Latin and provided Galenic medicine with a logical backbone."35

The dissemination of medical knowledge included the treatment of all manner of ailments - including wounds. However, the emergence of surgery as a separate discipline led to more sophisticated wound treatment. Probably the earliest surviving surgical compilation from medieval Europe is the Chirurgia (c. 1180) of Roger Frugard, which was translated into French and among the earliest manuals to reach England. ${ }^{36}$ Lanfranc of Milan (c. 1250-1306) wrote

32 Green, introduction, 10.

33 Green, introduction, 10-11.

34 Roy Porter, The Greatest Benefit to Mankind: A Medical History of Humanity (New York: W.W. Norton, 1997), 113 .

35 Porter, The Greatest Benefit to Mankind, 108-9. While many of these manuals give bad advice by modern standards, in their own time they offered logical remedies and diagnoses. Modern medicine has debunked much of what these manuals say, but in some cases, the efficacy of their techniques and treatments are being reconsidered.

$3^{6}$ The Latin text is edited by Karl Sudhoff, "Die Chirugie von Roger Frugardi von Salern," in his Beiträge zur Geschichte der Chirurgie im Mittelalter, vol. 2 (Leipzig: Johann Ambrosius Barth, 1918), 148-236, and discussed comprehensively in Helen Valls, "Studies on Roger Frugardi's Chirurgia" (PhD dissertation: University of Toronto, 1995). See: Tony Hunt, Anglo-Norman Medicine, vol. 1, Roger Frugard's Chirurgia and the Practica brevis of Platearius (Cambridge: D.S. Brewer, 1994), 5-8, for the French. See also: Roger Frugard, Surgery, trans. Michael R. McVaugh, in Sourcebook in Medieval Science, ed. Edward Grant (Cambridge, MA: Harvard University Press, 1974), 795-96 (no. 112). Frugard is known variously as Roger Frugardi, Ruggero Frugardo, and Roger of Salerno, but in the interests of consistency, all the articles in this volume refer to him as Roger Frugard. 
another early treatise on surgical practice, Chirurgia magna (Grand Surgery), but it was Henri de Mondeville (c. 1260-1320), in his unfinished Cyrurgia (started in 1306), who dealt more thoroughly with wound treatment. ${ }^{37}$ Mondeville opposed the Hippocratic view that advocated for suppuration pus formation - preferring dry healing instead; that is, the simple bathing of wounds, immediate closure by suture, and dry dressings with minimal loss of flesh or skin. ${ }^{38}$ His disciple Theoderic (1205-96) supported his assertion in his own Chirurgia that pus formation was unnecessary.

These surgical innovations in wound treatment were met with some opposition from the Salernitan School; but they provided a logical foundation for the surgeons of later generations. Guy de Chauliac (1298-1368) shows surgery as a learned art in his Chirurgia magna, which covers anatomy, inflammation, wounds, ulcers, fractures, dislocations, and miscellaneous diseases requiring surgery, and includes no fewer than 3299 references to other works, 890 of which are from Galen. ${ }^{39}$ Guy de Chauliac's work was translated into several languages and disseminated throughout medieval Europe, laying a medical foundation for the surgical treatment of wounds.

As Woosnam-Savage and DeVries explain, one example of wound repair that strikes a visual cord with modern audiences is the often-reproduced image of "The Wound Man." There are several late-medieval and early modern examples of this medical aid still extant, but one of the best known and most detailed is "The Wound Man" (c. 1420) from Thuringia that survives in London, Wellcome Library MS 49, fol. 35r (Figure 1.1). This color image depicts a man riddled with wounds from daggers to the thigh and torso, arrow and quarrels to the legs, lacerations, bee and scorpion stings, spider and snakebites, and a variety of head wounds. As Bettina Bildhauer points out, it is an image of a "porous, permeated and leaking body," vulnerable and under threat but also "about to be treated and hopefully healed." 40 Treating wounds was as significant a part of medieval life as inflicting them and the bulk of surviving medical manuals offer a range of remedies and surgical procedures for wound repair.

Not all medical texts deal overtly with surgical practice, but Debby Banham and Christine Voth argue that there is evidence in works like Bede's Historia ecclesiastica (731) that surgery and the treatment of wounds was a common occurrence. They examine Old English texts like Bald's Leechbook, London,

37 Porter, The Greatest Benefit to Mankind, 116-17.

38 Pierre Huard and Mirko Drazen Grmek, Mille ans de chirurgie en occident: Ve-XVe siècles (Paris: R. Dacosta, 1966), 40.

39 Porter, The Greatest Benefit to Mankind, 117.

40 Bildhauer, Medieval Blood, 27. 
British Library, Royal MS 12 D. xvii (s. $\left.\mathrm{x}^{\mathrm{i}}\right)(B L B)^{41}$ and two in Leechbook III (73 chapters, in the same manuscript),$^{42}$ which suggest that there was a medical culture that included surgical practices of some kind in Anglo-Saxon England. Analyzing the paucity of direct evidence regarding surgical treatments in Old English sources, Banham and Voth conclude that anatomical and surgical knowledge was drawn on in composing the law codes and that most "mechanical processes, whether surgical or pharmacological, were excluded from the medical texts because they were too familiar to need writing down, being part of the body of knowledge transmitted by non-textual means."43

Timothy May investigates the detailed textual accounts of practical medicine among the Mongols, with particular attention to the wounds sustained by Chinggis Khan in 1201 and the ways in which those wounds were treated. Far from using primitive, unsuccessful, or dubious medical treatments, May posits that the Mongols employed techniques for preventing shock, cleaning wounds, and halting blood loss not unlike modern methods. In fact, modern medicine has recently rediscovered the beneficial properties of honey as a disinfectant and anti-microbial agent, of which medieval people were well aware. ${ }^{44}$ Ilana Krug presents compelling evidence that honey was kept in large stores in some medieval castles specifically for its medical properties and that it was a vital resource during siege warfare. The use of honey provides evidence of how the expertise of medieval military surgeons has been underappreciated. Krug concludes: "The fact that many, if not most, of those wounds healed without infection highlights the importance of honey in medieval military medicine and the need to keep some handy." 45 Using some of the same material as Krug, Michael Livingston provides a detailed case study of this surgical expertise, especially the benefits of honey, in his examination of Prince Hal's face wound, received during the battle of Shrewsbury (21 July 1403). The future King Henry $\mathrm{v}$ was severely wounded by an arrow, which buried itself six inches into his

41 T.O. Cockayne, ed., Leechdoms, Wortcunning and Starcraft of Early England, 3 vols. (London: Rolls Series, 1864-6), 2:2-298.

42 Cockayne, Leechdoms, 2:300-6o.

43 Debby Banham and Christine Voth, "The Diagnosis and Treatment of Wounds in the Old English Medical Collections: Anglo-Saxon surgery?” in this volume, 153-74, at 173. See also: Debby Banham, "A Millennium in Medicine? New Medical Texts and Ideas in England in the Eleventh Century," in Anglo-Saxons: Studies Presented to Cyril Roy Hart, ed. Simon Keynes and Alfred P. Smyth (Dublin: Four Courts Press, 2006), 230-42.

44 Timothy May, "Spitting Blood: Medieval Mongol Medical Practices," in this volume, $175^{-93}$.

45 Ilana Krug, "The Wounded Soldier: Honey and Late Medieval Military Medicine," in this volume, 194-214, at 214. 
face, and was subsequently (and successfully) treated by the London surgeon John Bradmore, who kept a detailed account of his treatment and his patient's progress during the procedures used to heal the wound. Livingston goes through each of the sources regarding this famous wound, sketching a clear picture of how these wounds were treated, the effects of penetrating facial wounds, and the implications this injury had for the prince once he became king. For Prince Hal, his wound may have marked him in more ways than one; indeed, the memory of his injury may have been imprinted on more than just his face. ${ }^{46}$

\section{Law}

Wounds like Prince Hal's could have legal consequences. Certain wounds might be used to exclude men from a line of succession or to disinherit them. ${ }^{47}$ Those who were wounded and survived with evidence of their wounding inscribed on their bodies often had legal recourse depending on the nature of their wounds. In medieval law, wounds often required compensation; they could be adjudicated, weighed, measured, and compensated. Wounds were also inflicted in the course of administering justice. As Bildhauer explains, "the integrity of the body was at stake: once an offender had pierced the body and thereby called into question its inviolability, his or hers had to be pierced in return." 48 The body of the criminal was wounded to reflect his crimes; it became a canvas "for the public inscription of punishment." ${ }^{\text {"9 }}$ According to Allie Terry-Fritsch, "The criminal's wounds served as material traces of wrongs that had been righted through the cleansing ritual of the government, edifying the public through a reinscription of communal values and educating the public in behavioral and societal norms." ${ }^{50}$

46 Michael Livingston, “The Depth of Six Inches': Prince Hal's Head-Wound at the Battle of Shrewsbury," in this volume, 215-30.

This is particularly true of genital wounds, regardless of how those wounds were sustained. See: Castration and Culture in the Middle Ages, ed. Larissa Tracy (Cambridge: D.S. Brewer, 2012).

48 Bildhauer, Medieval Blood, 64.

49 Allie Terry-Fritsch, "Proof in Pierced Flesh: Caravaggio's Doubting Thomas and the Beholders of Wounds in Early Modern Europe, in Beholding Violence in Medieval and Early Modern Europe, ed. Terry-Fritsch and Erin Felicia Labbie (Burlington, vT: Ashgate, 2012), 15-37, at 18 .

$50 \quad$ Terry-Fritsch, "Proof in Pierced Flesh," 21. 
The inherent brutality of medieval jurisprudence is a contested issue that has met with serious challenge, especially regarding the use of torture in the Middle Ages. ${ }^{51}$ Wounds were inflicted in medieval jurisprudence and when they healed they remained a signifiers of crime and criminality for both the criminal and the victim. Jay Paul Gates and Nicole Marafioti provide an extended discussion of criminal penalties in Anglo-Saxon England that resulted in serious wounding and mutilation. ${ }^{52}$ However, the principle focus in this volume is not penal wounds inflicted as payment for a crime, but the legal ramifications of wounds and the role that physicians played in their adjudication..$^{53}$

In the legal arena of medieval Valencia, physicians were called upon as medical witnesses in cases where amputation was deemed necessary. In a practice seemingly unique to Valencia, Carmel Ferragud examines instances in which physicians were summoned by judges to testify about the necessity of an amputation desired by the patient. Amputations were dangerous because of the risk of infection and blood loss, not to mention the potential for loss of livelihood, and yet there are occasions when patients requested that a wounded limb that would not heal be removed. For that, a judge had to agree and, in a legal society adverse to risk, a physician was required to testify. ${ }^{54}$ Ferragud traces the evidence of this practice and its ramifications for medical culture in medieval Valencia, while Charlene Eska analyzes the legal implications of literary wounds in medieval Ireland. In her analysis of Aided Derbforgaill (The Violent Death of Derbforgaill), Eska argues that the mutilation enacted upon Derbforgaill by the Ulster women is "calculated not only to destroy her beauty in a distinctly gendered way, but also to destroy her social existence by rendering her appearance a source of public shame in terms of Irish cultural norms."55 She applies the Irish law codes regarding adultery to the literary text, explain-

See: Tracy, Torture and Brutality; and Larissa Tracy and Jeff Massey, eds., Heads Will Roll: Decapitation in the Medieval and Early Modern Imagination (Leiden: Brill, 2012), among others.

Jay Paul Gates and Nicole Marafioti, eds., Capital and Corporal Punishment in Anglo-Saxon England (Woodbridge: Boydell Press, 2014).

For a detailed historical analysis on the intersection of medicine and law, including the use of medical professionals as legal witnesses, see: Turner and Butler, eds., Medicine and the Law in the Middle Ages. Several articles in this volume compliment their research and supplement their findings.

Carmel Ferrgaud, "Wounds, Amputations, and Expert Procedures in the City of Valencia in the Early-Fifteenth Century," in this volume, 233-51.

55 Charlene M. Eska, "The Mutilation of Derbforgaill," in this volume, 252-64, at 253. 
ing how this kind of wounding may have been received - and potentially condemned - within Irish society.

\section{Spiritual Wounds}

The wounds of Christ, the stigmata, are one of the foundational aspects of medieval Christian belief. Devotional art, literature, and material culture depict graphic scenes of torture and execution, evoking a sympathetic response to the blood-soaked, wounded figures of Christ and his saints. So much so that, as Caroline Walker Bynum has argued, by the later Middle Ages, these forms of religious iconography "seem awash with blood." 56 She writes that by the late fourteenth century, "devotions to the five wounds; to the side wound, and to the wounded heart were proliferating; the faithful were urged to count Christ's lesions and the number of blood drops he shed, using such number to calculate the prayers they owed for their own sins or those of their loved ones suffering in purgatory." ${ }^{57}$ In depictions of the Passion the wounds of Christ are symbols of both his divinity and his corporeality; without the physical wounds, medieval and early modern Christians could not experience Christ's sacrifice. These wounds are proof that serves "both as traces of violence and as representations of higher ideals." 58 The wounded body functions as "proof" not only in the context of Christian devotion but in the practice of justice - a discourse in which the crucifixion, as a punishment for a criminal in the eyes of Rome, participates. Wounding is a social and physical purgative.

In the section on spiritual wounds, Virginia Langum probes depictions of Christus medicus (Christ the Physician) as compassionate, arguing that the crucifixion wound becomes a surgical wound "when Christ adopts the role of a surgeon to attach the faithful to it." ${ }^{59}$ Langum applies the technical medical discussion of medieval surgery, echoing the earlier chapters in this volume, to visions of Christ's Passion and Christ as both physician and surgeon. The wounds of Christ, imagined in a multitude of ways in the Middle Ages, become the locus of Christian devotion and adoration, which Langum suggests, is presented in medical terms. In Irish bardic poetry, the wounds of Christ are juxtaposed with those of Gaelic chieftains wounded in battle. Following a

\footnotetext{
$5^{6} \quad$ Bynum, Wonderful Blood, 1-2.

57 Bynum, Wonderful Blood, 3.

$5^{8}$ Terry-Fritsch, "Proof in Pierced Flesh," 17.

59 Virginia Langum, “The Wounded Surgeon': Devotion, Compassion and Metaphor in Medieval England," in this volume, 269-90, at 270.
} 
similar line of inquiry as Langum, Salvador Ryan analyzes the relationship of poet and patron in the corpus of bardic poetry where Christ's heroism in the face of violent wounding is a metaphor for the physical, temporal wounds of the secular chieftain..$^{60}$

While the use of religious imagery as an aid to devotion is relatively rare in bardic poetry, it was a common occurrence in religious art, in which the wounds of Christ and the saints were a popular visual stimulant for faith. Vibeke Olson applies an art historical lens to the wounded Christ, considering artistic representations of the stigmata, like Hans Memling's late fifteenth-century painting, Man of Sorrows, and the performative space offered by graphic depictions of the crucifixion and Christ's wounds. In her analysis of several works of art, Olson discusses the shift in focus from all five wounds of the stigmata to a particular emphasis on Christ's side wound, even to the point of abstracting it from the body itself. ${ }^{61}$ The wound and the blood it produces become the locus for salvation and devotion, inviting direct and intimate participation from the faithful. Similarly, Elina Gertsman investigates the wandering side-wound of Christ in a late fifteenth-century German woodcut printed in Ulm, a representation that takes on political significance in the face of Jewish expulsions and clerical transgressions. Gertsman draws compelling parallels between Christ's wounded body and the urban body politic, arguing that the wounded Christ was endowed with both political and religious significance, especially in anti-Judaic propaganda. ${ }^{62}$

In their attempts at imitatio Christi, some saints wounded themselves or experienced the mystical wounds of the crucifixion. While early Christian saints had the capacity and the opportunity to suffer violent and horrible wounding at the hands of Roman persecutors, late-medieval saints had to celebrate the destruction and denigration of their bodies for the faith in other ways. Since the crown of martyrdom was unavailable to them, late-medieval saints experienced salvific wounds through a variety of afflictions, including penitential self-mutilation, leprosy, and blindness. ${ }^{63}$ As Esther Cohen argues, these saints embraced pain as a way to dominate it. She writes that rather than

6o Salvador Ryan, "Scarce anyone survives a heart wound': The Wounded Christ in Irish Bardic Religious Poetry," in this volume, 291-312.

61 Vibeke Olson, "Penetrating the Void: Picturing the Wound in Christ's Side as a Performative Space," in this volume, 313-39.

62 Elina Gertsman, "Wandering Wounds: The Urban Body in Imitatio Christi," in this volume, $340-65$.

63 On the differences in early versus later "martyrdom", see: Clare Stancliffe, "Red, White and Blue martyrdom," in Ireland in Early Mediaeval Europe: Studies in Memory of Kathleen Hughes, ed. Dorothy Whitelock, Rosamond McKitterick, and David Dumville (Cambridge: Cambridge University Press, 1982). 
being enslaved "by a ferocious force that could dehumanize people, ascetics and self-inflictors became masters of pain, embracing it freely and using their sensations to reach new levels of spirituality."64 Wilbirg of St. Florian ( $\dagger 1289)$, Christina the Astonishing ( $† 1224)$, and the Cistercian nun Lutgard of Aywières $(\dagger 1246)$ all inflicted grievous wounds on themselves as a means of achieving spiritual gratification, as Joshua Easterling explains. ${ }^{65}$ Easterling considers how saints wounded themselves to achieve a form of imatatio Christi and the community response to their physical sacrifice. Alice of Schaerbeek (†1250) known as Alice the Leper - relished the suppurating wounds that erupted on her flesh as a mark of God's love. According to Alicia Spencer-Hall, Alice saw her disease as a way of glorifying God; her decaying skin and oozing wounds became a testament to her faith. ${ }^{6}{ }^{6}$ In her analysis, Spencer-Hall focuses on the hagiographical appropriation of leprous wounds as a form of ascetic suffering, while Albrecht Classen interrogates the life-long (self-inflicted) suffering of Prussian mystic Dorothea von Montau (1347-1394). Like many of the mystics discussed by Easterling, Dorothea von Montau assaulted her own body as "a metaphor and catalyst for the transformation of the material existence into a basis for spiritual, mystical experiences." ${ }^{67}$ Classen explores the layers of meaning exposed by Dorothea's extreme behavior, concluding that she saw the wounding of her body as a means of preparing her flesh to be God's parchment upon which his presence could be written. In the hagiography of Ireland, saints not only experienced salvific wounds themselves but were able to inflict wounds - often to the eyes - as a measure of their spiritual power. Máire Johnson turns the conversation to the agency of Irish saints, not only in healing wounds but also in creating them to punish others and themselves. Like Gertsman, Johnson considers the political implications of sanctity, but, similar to Eska, she uses legal terms to investigate the social ramification of hagiographical wounding. As Johnson illustrates, saints like Ciarán of Saigir and Mochutu curse those who challenge their authority so that their eyes burst in their sockets, one eye is plucked out and left dangling on the offender's cheek, or the guilty party is simply left blind. Johnson places these punitive blindings, and the occasions where female Irish saints like Brigit restore sight, in a legal

\footnotetext{
64 Cohen, The Modulated Scream, 28.

65 Joshua S. Easterling, "Ascetic Blood: Ethics, Suffering and Community in Late-Medieval Culture," in this volume, 369-88.

66 Alicia Spencer-Hall, "Christ's Suppurating Wounds: Leprosy in the Vita of Alice of Schaerbeek ( $\dagger 1250)$, , in this volume, $389-416$.

67 Albrecht Classen, "Wounding the Body and Freeing the Spirit: Dorothea von Montau's Bloody Quest for Christ, a Late-Medieval Phenomenon of the Extraordinary Kind," in this volume, $417-47$, at 419 .
} 
context, arguing that an "Irish saint thus defines the line between those who are participants in and those excluded from the Irish body Christian, through the media of both maledictory eye wounds and their merciful remission." 68

\section{Literature}

Religious literature is populated by wounded saints whose suffering (or lack thereof) is a signifier of their holiness and a testament to their devotion. But wounds in secular literature take on an entirely different meaning, especially in the context of medieval romance. In The Knight's Tale, Chaucer's Knight describes the shafts of spears shivering to pieces on thick shields, the 'helmes they tohewen and toshrede;/ Out brest the blood with stierne stremes rede;/ With myghty maces the bones they tobreste' (lines 26o9-11). ${ }^{69}$ Yet, for all this bloodshed, no one dies and the only malice and hatred is between the two rivals (Arcite and Palamon) who hunt each other down and with 'jelous strokes on hir helmes byte;/ Out rennet blood on bothe hir sydes rede' (lines 2634-5). Even in the final tally after Arcite's fall, 'Al were they soore yhurt, and namely oon, that with a spere was thirled his brest boon' (lines 2709-10); some have broken bones, some apply salves and medicines, and some drink sage to save their limbs. The Knight's description of Arcite's injuries is far more graphic than the scenes of battle. When Arcite falls, he lies as if dead, 'His brest tobrosten with his sadel-bowe./ As blak he lay as any cole or crowe,/ So was the blood yronned in his face' (lines 2691-3). The clotted blood, despite the efforts of leechcraft, decays and cannot be drained through any medical techniques, and the poison cannot be expelled: 'The pipes of his longes gonne to swelle,/ And every lacerte in his brest adoun/ Is shent with venym and corrupcioun' (lines $275^{2-4}$ ). It is a gruesome and painful death, fraught with lurid detail lacking in the earlier scenes of battle.

Chaucer's description of these battle wounds, which possibly reflected his own experience with combat, are a literary template for understanding the significance of wounds in secular texts. In the heroic narratives of early medieval Ireland, like those in the Ulster Cycle, wounds signify battle prowess, glory, and honor. Using some of the same sources as Eska but from a literary angle, William Sayers explains that in Togail Bruidne Da Derga (The Destruction of Da Derga's Hostel) the "contrast between white wounds (créchda bána) and red,

68 Máire Johnson, "In the Bursting of an Eye: Blinding and Blindness in Ireland's Medieval Hagiography," in this volume, 448-70, at 451.

69 Geoffrey Chaucer, Canterbury Tales, in The Riverside Chaucer, ed. Larry D. Benson, 3rd ed. (Boston: Houghton Mifflin, 1987). Lines numbers are given in parentheses. 
between the dormant scars that are the heritage of combat and the immediate, living, bleeding wounds of battle, goes to the heart of the early Irish conception of the human body as an incarnation of heroic honor."70 As in Skinner's analysis of the potential shaming aspects of head and facial wounds, Sayers pays particular attention to the effect that scars had on social status and a warrior's position in society as well as the scarring effect of battle on the landscape. In medieval Irish society, wounds that healed into scars could often provide fodder for harsh satire, but, ultimately, scars could shape the narratives of honor and dishonor.

Sayers argues that wounds are the very "makings of epic literature,"71 a statement that holds true for much of medieval romance, concerned as it is with chivalric combat and its consequences. The corpus of medieval Arthuriana, particularly in England, includes a litany of wounds with varying degrees of severity. Within the literary tradition surrounding King Arthur and his Round table knights, wounds reflect actual chivalric practice, as Stephen Atkinson argues about Thomas Malory's Morte Darthur, but they can also serve as a metaphor for the body politic. Larissa Tracy draws a connection to the succession of head wounds in the Stanzaic Morte Arthur and the political instability of late-fourteenth century England. In this version of Arthur's death, Lancelot, Gawain, and Arthur all receive blows to the head that incapacitate and eventually kill (except Lancelot), leaving Arthur's kingdom headless, weak, and debilitated by internal strife similar to that of Richard II and his rebellious barons. ${ }^{72}$ Even in the romance context, battle wounds have lasting and far-reaching consequences beyond the point of impact. Atkinson argues that Malory was intent on realism in his descriptions of battle wounds, which, like Chaucer, he may have witnessed first-hand. ${ }^{73}$ In a reflection of Eska's earlier piece on the gendered mutilation of Derbforgaill, Barbara Goodman analyzes the collateral damage of warfare in romances. The wounds of women in texts like Malory, The Siege of Jerusalem, and the Alliterative Morte Arthur are not presented as valorous or excusable costs of war but rather reveal the fractures in the social fabric and fissures in the heroic and chivalric ideals. 74

In many respects, wounds defy easy categorization because each instance of wounding held its own significance; those who were wounded internalized

70 William Sayers, "The Laconic Scar in Early Irish Literature," in this volume, 473-95, at 474.

71 Sayers, "The Laconic Scar," 494.

72 Larissa Tracy, “Into the hede, throw the helme and creste': Head Wounds and a Question of Kingship in the Stanzaic Morte Arthur," in this volume, 496-518.

73 Stephen Atkinson, "They ... toke their shyldys before them and drew oute their swerdys ...": Inflicting and Healing Wounds in Malory's Morte Darthur," in this volume, 519-43.

74 Barbara A. Goodman, "Women's Wounds in Middle English Romances: An Exploration of Defilement, Disfigurement, and a Society in Disrepair," in this volume, 544-70. 
them in respect to their suffering or the lack of suffering. Wounds could mean honor and chivalry, or they could mean dishonor and criminality. A wound could involve the removal of a limb (Ferragud) or an eye (Johnson), the lacerations inflicted in battle, incisions made during medical treatment, or ulcers caused by disease like leprosy (Spencer-Hall). This volume considers wounding from the multitude of perspectives available from medieval sources: archaeology, art, chronicle, literature, and law, from a range of geographical settings throughout the medieval world. Overall, the intent is to construct a nuanced and textured view of medieval wounds, their consequences, their symbolism, their effect on the body in society, and their place in understanding human nature, resilience, and devotion.

In her summation on the complexity of wounding and healing in the Middle Ages, Wendy Turner offers a final analysis of the pieces in this volume. Turner draws upon the thesis of Carlo Ginzburg, who advocates historical investigation from a multitude of multidisciplinary and interdisciplinary perspectives. ${ }^{75}$ As Turner explains, that has been the primary goal of this project since its inception. Within this volume archaeologists look at literary records as well as the archaeological record; historians and weapons experts consider physical evidence and literary sources; art historians sharpen their creative vision through political and social texts; and literary historians use surgical manuals, chronicle accounts, and legal precedent to illuminate the textured readings of wounds in the Middle Ages. We draw upon many of the same sources and so we have compiled a complete bibliography at the end to aid in further collaborative, interdisciplinary endeavors.

Wounds abound in the medieval world in images, discussions, representations, and cultural interest not because there was a greater delight in bloodshed or violence but because wounds open the body to investigation and inquiry; they test the boundaries of mortality, and they were something that people lived with and from which they often died. Medical advancements (and retreats) were a major facet of medieval society. The Church was deeply concerned about the integrity of the body, its wholeness and corruptibility, and battle and war were inscribed on the flesh of those who survived it. Considering the fragility and resilience of the human form, wounds are a way of measuring the human experience. This volume seeks to contribute a greater understanding of that experience in the medieval world so that we might better understand the significance of wounds - their infliction, treatment, stigmatization and lasting consequences - in modern society.

Carlo Ginzburg, Threads and Traces: True False Fictive, trans. Anne C. Tedeschi and John Tedeschi (Berkeley: University of California Press, 2012), 55 and 70 qtd. in Wendy J. Turner, "Afterword: The Aftermath of Wounds," in this volume, 572-80. 


\section{PART 1}

\section{The Physicality of Wounds}




\section{SECTION 1}

\section{Archaeology and Medieval Culture}

